medRxiv preprint doi: https://doi.org/10.1101/2021.02.26.21251982; this version posted March 2, 2021. The copyright holder for this preprint

(which was not certified by peer review) is the author/funder, who has granted medRxiv a license to display the preprint in perpetuity.

All rights reserved. No reuse allowed without permission.

\title{
The kidney produces a non-polymerizing form of Uromodulin that associates with reduced risk of acute kidney injury
}

\author{
Radmila Micanovic ${ }^{1}$, Kaice A. LaFavers ${ }^{1}$, Kavish R. Patidar ${ }^{2,3}$, Marwan S. Ghabril ${ }^{2,3}$ \\ Shehnaz Khan ${ }^{1}$ and Tarek M. El-Achkar ${ }^{1,4,5,6}$ \\ ${ }^{1}$ Division of Nephrology and Hypertension, Indiana University School of Medicine, Indianapolis, IN, USA \\ ${ }^{2}$ Division of Gastroenterology and Hepatology, Department of Medicine, Indiana University School of \\ Medicine, Indianapolis, Indiana, USA \\ ${ }^{3}$ Indiana Center for Liver Research, Indiana University School of Medicine, Indianapolis, Indiana, USA \\ ${ }^{4}$ Department of Cellular and Integrative Physiology, Indiana University School of Medicine, Indianapolis, \\ IN, USA \\ ${ }^{5}$ Department of Anatomy and Cell Biology, Indiana University School of Medicine, Indianapolis, IN, USA \\ ${ }^{6}$ Roudebush VA Medical Center, Indianapolis, IN, USA
}

Correspondence:

Tarek M. El-Achkar (Ashkar), MD 950 W Walnut St.

$\mathrm{R} 2-\mathrm{E} 280$

Indianapolis, IN 46202

Email: telachka@iu.edu 
medRxiv preprint doi: https://doi.org/10.1101/2021.02.26.21251982; this version posted March 2, 2021. The copyright holder for this preprint (which was not certified by peer review) is the author/funder, who has granted medRxiv a license to display the preprint in perpetuity. All rights reserved. No reuse allowed without permission.

\section{Abstract}

Uromodulin (Tamm-Horsfall protein, THP) is a glycoprotein uniquely produced in the kidney. It is released by cells of the thick ascending limbs (TAL) apically in the urine, and basolaterally in the renal interstitium and systemic circulation. Processing of mature urinary THP, which polymerizes into supra-molecular filaments, requires cleavage of an external hydrophobic patch (EHP) at the $\mathrm{C}$ terminus. However, THP in the circulation is not polymerized, and it remains unclear if non-aggregated forms of THP exist natively in the urine. We propose that an alternative processing path, which retains the EHP domain, can lead to a non-polymerizing form of THP. We have generated an antibody that specifically recognizes THP with retained EHP (THP+EHP) and established its presence in the urine in a non-polymerized native state. In the human kidney, THP+EHP predominantly co-localized with urinary THP in TAL cells, but it was also detected, at lower levels, in other tubular segments. We then developed a customized ELISA to measure THP+EHP and used it on urine and plasma samples from a small cohort of patients hospitalized with liver cirrhosis. On admission, urinary THP+EHP, but not total THP, was significantly lower in patients who subsequently developed acute kidney injury during hospitalization. THP+EHP was also detected in the plasma, albeit at very low concentrations. Our findings uncover novel insights into uromodulin biology by establishing the presence of an alternative path for cellular processing. Our proof-ofprinciple findings in patients warrant further investigations to establish the utility of THP+EHP as a sensitive biomarker of kidney health and susceptibility to injury. 
medRxiv preprint doi: https://doi.org/10.1101/2021.02.26.21251982; this version posted March 2, 2021. The copyright holder for this preprint (which was not certified by peer review) is the author/funder, who has granted medRxiv a license to display the preprint in perpetuity. All rights reserved. No reuse allowed without permission.

\section{Introduction}

Uromodulin, (also known as Tamm-Horsfall protein, THP) is a glycoprotein uniquely produced by the epithelial cells lining the thick ascending limb (TAL) of the loop of Henle and early distal convoluted tubule (1-3). Its exclusive renal expression, great urinary abundance and phylogenetic conservation point to important physiological roles that are of interest to researchers and clinicians. THP is predominantly sorted to the apex of TAL cells and secreted into the urine as one of the most abundant proteins $(4,5)$. A lesser, but significant amount of THP is released basolaterally, towards the renal interstitium and systemic circulation $(6,7)$. The concentration of THP in the circulation is approximately a thousand times lower than the urine $(8,9)$.

The last two decades have uncovered important roles for urinary and serum THP in regulating renal homeostasis and modulating response and susceptibility to injury. The polymerization of urinary THP is thought to be a key factor in maintaining the impermeability of the TAL segment to water (10). Furthermore, THP filaments play a key role in host defense against ascending infections by binding to bacteria and aiding in pathogen clearance $(11,12)$. Within the cells where it is produced, THP facilitates the activation of the NKCC2, ROMK and NCC channels, which has key implications on distal handling of salt and hypertension (13-17). Furthermore, THP regulates calcium and magnesium handling by regulating TRPV5 and TRPM6 channels, respectively (18, 19).

THP is basolaterally released in the renal interstitium and subsequently in the bloodstream (7). In the renal interstitium, THP affects multiple cell types, such as S3 proximal tubules, where it inhibits pro-inflammatory signaling $(20,21)$, and immune cells, where it regulates the abundance and phagocytic activity of resident mononuclear phagocytes (MPCs) and protects against inflammation following kidney injury (22). THP 
medRxiv preprint doi: https://doi.org/10.1101/2021.02.26.21251982; this version posted March 2, 2021. The copyright holder for this preprint (which was not certified by peer review) is the author/funder, who has granted medRxiv a license to display the preprint in perpetuity. All rights reserved. No reuse allowed without permission.

has also important systemic effects on other organs, such as regulation of granulopoiesis, vascular calcification and mitigation of oxidative stress through inhibition of the TRPM2 channel (23-25). Many studies have evaluated the role of both serum and urinary THP as biomarkers. A growing body of compelling evidence suggests that the presence of high levels of THP (in the urine or serum) is independently associated with reduced risk of incident acute and chronic kidney disease, kidney disease progression, cardiovascular disease and mortality outcomes (8, 26-34). In addition, THP serum levels are inversely correlated with markers of systemic inflammation $(35,36)$.

Important advancements have been made to delineate the biosynthesis, intracellular maturation along the secretory pathway, excretion and polymerization of mature urinary THP (37-41). In contrast, little is known about the synthesis, cellular sorting and secretion of circulating THP. We have previously demonstrated that in contrast to urinary THP, circulating THP is not aggregated (22). However, it remains unknown how the kidney produces a non-polymerizing form of THP. The THP precursor is comprised of 614 amino acids. The predicted structural domains of THP include four epidermal growth factor (EGF)-like domains, a cysteine rich domain of unknown function (D8C) and a bipartite C-terminal zona pellucida domain (ZP, comprised of ZP-N and ZP-C sub-domains), essential for THP assembly into extracellular urinary polymers of supramolecular structure (2). An extensive hydrophobic interface mediates the ZP-N domain homodimerization, while a structured interdomain linker between ZP-N and ZPC directs that self-association (37). During intracellular trafficking, THP is kept in a polymerization-incompetent state by the hydrophobic interaction of two motifs, the internal (IHP, residues 430 - 436 and 456 - 462) and external (EHP, residues 598 607) hydrophobic patches (42). The IHP is located in the ZP linker region, while the EHP resides between the consensus proteolytic cleavage site (F587) and GPI 
medRxiv preprint doi: https://doi.org/10.1101/2021.02.26.21251982; this version posted March 2, 2021. The copyright holder for this preprint (which was not certified by peer review) is the author/funder, who has granted medRxiv a license to display the preprint in perpetuity. All rights reserved. No reuse allowed without permission.

anchoring site (S614) at the apical membrane on the urinary lumen side. Proteolysis by the type II transmembrane serine protease hepsin at conserved F587 removes the EHP motif, thus permitting correct orientation of ZP-N domains for polymerization to occur in the urine $(43,44)$. Although monomeric forms of THP in the urine have been recovered, these only occurred after treatment with a chaotropic agent and/or truncation $(22,45)$.

Based on our knowledge of the structure of THP and the mechanisms of its polymerization, we aimed to 1) determine how the kidney could natively produce a nonpolymerizing form of THP; 2) assess whether this knowledge will advance our understanding of the biology of its apical vs. basolateral release; 3) gage the potential clinical implications and advantages of measuring such form of THP. We hypothesized that a non-polymerizing form of THP could be present if a molecular event (such as cleavage at an alternative site) causes retention of the EHP and thereby releases a longer form of THP (very similar to the precursor sequence). Therefore, we designed and optimized tools to detect and measure THP with retained EHP (referred to as THP+EHP) and performed preliminary studies to assess the usefulness of measuring THP+EHP in a clinical setting. 
medRxiv preprint doi: https://doi.org/10.1101/2021.02.26.21251982; this version posted March 2, 2021. The copyright holder for this preprint (which was not certified by peer review) is the author/funder, who has granted medRxiv a license to display the preprint in perpetuity. All rights reserved. No reuse allowed without permission.

\section{Methods}

Generation of anti-peptide antibody for detection of non-polymerizing THP: A rabbit polyclonal antibody recognizing the EHP region of human THP (anti-EHP pAb) was generated by Biomatic (Ontario, Canada). The synthetic peptide corresponding to human THP amino acids 591 - 612 (C-SVIDQSRVLNLGPITRKGVQAT) was used in immunizations (conjugated to keyhole limpet hemocyanin protein) and for antigenaffinity purification of the antibody.

Western blot: Western blot was performed as described previously (22). The following primary antibodies were used: sheep anti-hTHP (R\&D Biosystems AF5144) pAb and anti-EHP pAb; secondary antibodies used were rabbit anti-sheep IgG-HRP (AP147P; Millipore) and donkey anti-rabbit IgG-HRP (AP182P: Millipore). Bands were detected by enhanced chemiluminescence (Pierce Super Signal West Pico kit, \#34087) on ChemiDoc MP imaging system (BioRad, CA).

Native PAGE and immunoblot: Native polyacrylamide gel electrophoresis and immunoblot were performed using the Invitrogen 4-16\% NativePAGE Bis -Tris precast mini-gels and protocol (22).

Purification of human urinary polymerizing THP (pTHP): Purification of human urinary THP was carried out by salt precipitation of the aggregating THP from the urine, as described by Tamm and Horsfall $(46,47)$. THP precipitated from urine of normal human donors was subsequently treated with $8 \mathrm{M}$ urea for $>12$ hours at $4^{\circ} \mathrm{C}$ with tumbling. It was then concentrated on an Amicon concentrator with $10 \mathrm{kD}$ molecular weight cutoff 
medRxiv preprint doi: https://doi.org/10.1101/2021.02.26.21251982; this version posted March 2, 2021. The copyright holder for this preprint (which was not certified by peer review) is the author/funder, who has granted medRxiv a license to display the preprint in perpetuity. All rights reserved. No reuse allowed without permission.

(Millipore) and transferred on a Superdex 200 gel filtration column equilibrated with 30 $\mathrm{mM}$ phosphate buffer, $\mathrm{pH} 6.8$, in $2 \mathrm{M}$ urea (22). The column was pre-calibrated using specific molecular weight markers (BioRad, CA). THP fractions were collected and the protein concentration in each fraction was determined using a spectrophotometer. Native gel electrophoresis was performed on the recovered fractions followed by denaturing and reducing SDS-PAGE. For these experiments, fractions of THP with evidence of polymerization on native gel electrophoresis were pooled to form polymerizing $\mathrm{p}(\mathrm{THP})$.

ELISA for non-polymerizing (THP+EHP) THP detection: Custom sandwich ELISA for non-polymerizing THP detection was developed using a mouse anti-THP monoclonal antibody (sc-271022; Santa Cruz Biotechnology, CA) as a capture antibody and rabbit anti-EHP polyclonal antibody as the detection antibody. The detection was performed using donkey anti-rabbit IgG-HRP (Millipore EMD AP182P) and 3,3',5,5'Tetramethylbenzidine (TMB) Liquid Substrate System as peroxidase substrate (ThermoFisher Scientific, \#34028). The assay was performed using NuncImmuno $^{\mathrm{TM}}$ MaxiSorp $^{\mathrm{TM}} 96$ well solid plates (Sigma-Aldrich, M9410), 5\% BSA (ThermoFisher Scientific, \#N502) as a blocking solution, PBS/Tween $0.05 \% / 1 \%$ BSA as a washing solution, Stop Solution for TMB Substrates (ThermoFisher Scientific, N600) and standard sandwich ELISA protocol. The standard in the ELISA assay was a custom made 37 amino acid-long peptide comprised of mouse anti-hTHP mAb epitope (N-terminal) and EHP sequence (C-terminal). Minimum detectable level was between $50-100 \mathrm{pg}$ 
medRxiv preprint doi: https://doi.org/10.1101/2021.02.26.21251982; this version posted March 2, 2021. The copyright holder for this preprint (which was not certified by peer review) is the author/funder, who has granted medRxiv a license to display the preprint in perpetuity. All rights reserved. No reuse allowed without permission.

Tissue sectioning, immunofluorescence staining and confocal microscopy:

Immunofluorescence staining was performed, as described previously $(20,48)$ on 50 $\mu \mathrm{m}$ sections of $4 \%$ paraformaldehyde-fixed kidneys from a human nephrectomy specimen and sectioned using a vibratome. The following antibodies were used to visualize THP: Anti-Human Uromodulin Antibody, antigen affinity-purified polyclonal sheep IgG (R\&D Systems, AF5144) and custom made anti-EHP rabbit polyclonal antibody. DAPI was used for staining nuclei and Oregon Green Phalloidin (Molecular Probes, Eugene, OR) was used for staining F-actin. Confocal microscopy and image acquisition in 3 separate consecutive channels were performed using an Olympus Fluoview confocal microscope system (Japan). Images were collected under 4x and 20x magnification.

Quantitation of EHP fluorescence: Quantitation of EHP fluorescence was done on 3 separate fields from a human nephrectomy specimen (20x magnification) using ImageJ. The average intensity (after background subtraction) was measured separately in each tubule (marked as a region of interest) using a brush tool. The background average intensity was measured in negative controls without primary antibody.

Immunoprecipitation of serum THP: Normal human serum was purchased from EMD Millipore. Immunoprecipitation of THP from serum was performed in RIPA buffer using mouse anti-hTHP monoclonal antibody (B-2, Santa Cruz Biotechnology, sc-271022) or normal mouse IgG (Santa Cruz Biotechnology, sc-2343), both conjugated to agarose beads, for $>12$ hours at $4^{\circ} \mathrm{C}$. Binary antigen-antibody complexes were eluted with $4 \mathrm{X}$ SDS-PAGE sample buffer (1:2 ration of beads to buffer), and subjected to 
medRxiv preprint doi: https://doi.org/10.1101/2021.02.26.21251982; this version posted March 2, 2021. The copyright holder for this preprint (which was not certified by peer review) is the author/funder, who has granted medRxiv a license to display the preprint in perpetuity. All rights reserved. No reuse allowed without permission.

electrophoresis followed by Western blotting. Typically, 1 or $10 \mathrm{ml}$ of human serum was used in immunoprecipitations. The serum was initially depleted from IgGs by preincubation with high-capacity protein A/G agarose beads (ThermoFisher Scientific, \# 20423).

Epitope mapping of mouse anti-THP mAb: Mouse anti-hTHP monoclonal antibody B-2 (sc-271022) had a manufacturer's defined epitope region between amino acids 291 and 425 of human THP. To identify its true epitope a PepScreen approach was used from Sigma Aldrich. In short, a peptide library of 25 peptides, of 15 amino acids in length each and with 10 overlapping amino acids, was screened in a direct ELISA using biotinylated mouse anti-hTHP mAb B-2. The epitope peptide was identified to be THP amino acids $371-385$ and its sequence was used to generate a hybrid standard for nonpolymerizing THP ELISA.

ELISA for total THP detection: Total THP was measured in samples of human serum and urine using Human UMOD ELISA kit form Sigma-Aldrich (RAB0751).

Assay for total proteins in the urine: Total urinary protein content was determined by modified Lowry protein assay using a detergent compatible micro-assay kit (BioRad \# 5000112). 
medRxiv preprint doi: https://doi.org/10.1101/2021.02.26.21251982; this version posted March 2, 2021. The copyright holder for this preprint (which was not certified by peer review) is the author/funder, who has granted medRxiv a license to display the preprint in perpetuity. All rights reserved. No reuse allowed without permission.

Patient population and study protocol: The sample population was obtained from a cohort of hospitalized cirrhotic patients who were non-consecutively enrolled into a study evaluating urea metabolism. The study was approved by the Indiana University School of Medicine Institutional Review Board (approval number: 1011004299). The larger study from this cohort investigating the link between admission plasma THP and the risk of acute kidney injury had been previously reported (29). Inclusion criteria for the study included a known diagnosis of cirrhosis and age $\geq 18$ years. The diagnosis of cirrhosis was made based on clinical parameters involving laboratory tests, endoscopic or radiologic evidence of cirrhosis, evidence of decompensation (hepatic encephalopathy, ascites, variceal bleeding, jaundice), and liver biopsy, if available. Patients were excluded if there was an unclear diagnosis of cirrhosis, had prior solid organ transplantation, were admitted electively, or if informed consent could not be obtained. We further excluded patients who had active cancer, acute kidney injury (AKI) on admission, hemodialysis at the time of admission, and confirmed pregnancy (29). For the purposes of this current pilot study, we identified patients who developed AKI during hospitalization (defined as a rise in creatinine of $0.3 \mathrm{mg} / \mathrm{dL}$ or $50 \%$ increase from baseline, as recommended by Kidney Disease Improving Global Outcomes (49)) and had available blood and urine samples stored from the day of admission. 10 patients were identified, and they were matched for age, gender, baseline kidney function, and severity of cirrhosis (Model for End-stage Liver Disease) to another 10 patients who did not develop AKI. The case control matching was finalized a priori before any further testing was performed on the plasma or urine. Table 1 shows the baseline characteristic of this cohort. As expected, there were no significant differences between the two groups for demographics, co-morbid conditions, kidney function (baseline and admission), infections, and severity of cirrhosis. 
medRxiv preprint doi: https://doi.org/10.1101/2021.02.26.21251982; this version posted March 2, 2021. The copyright holder for this preprint (which was not certified by peer review) is the author/funder, who has granted medRxiv a license to display the preprint in perpetuity. All rights reserved. No reuse allowed without permission.

Statistical analysis: All statistical tests were performed using GraphPad Prism software unless otherwise noted. A two tailed t-test or the Wilcoxon rank sum was used to examine the difference in means for continuous data. A paired t-test was used for samples from the same patient collected at different times. An F-test was performed to test if the variances of the samples were significantly different and a Welch's t-test with correction was performed if the variances were found to be significantly different. For measurements with more than two groups, an ordinary one-way ANOVA was performed and significance between pairs of two groups was determined using Dunnett's multiple comparison tests. Only quantitative measurements which fell within the range of the calibrator measurement curve were used for analysis. Outlier measurements were identified according to the Tukey fence method and removed. Chi-squared and Fisher's exact tests was used to determine differences between categorical variables. Simple linear regressions were used to determine relationships between two continuous variables. Statistical significance was determined at $p<0.05$. 
medRxiv preprint doi: https://doi.org/10.1101/2021.02.26.21251982; this version posted March 2, 2021. The copyright holder for this preprint (which was not certified by peer review) is the author/funder, who has granted medRxiv a license to display the preprint in perpetuity. All rights reserved. No reuse allowed without permission.

\section{Results}

Establishing the presence of THP+EHP in the urine and its impaired polymerization. The annotated amino acid sequence of THP and its structural domains are shown in Supplemental Figure 1. To test the presence of THP+EHP, we designed, generated and characterized an anti-peptide antibody that recognizes the EHP sequence (Figure 1A). We then investigated and established the presence of THP+EHP in the urine using Western blot (Figure 1B). As expected, THP+EHP had a higher molecular weight $(>100$ $\mathrm{kDa}$ ) than urinary or purified polymerizing THP (the last two were detected using a sheep anti-THP polyclonal antibody raised against the mature urinary THP). The specificity of the anti-EHP antibody (Figure 1B, left panel) was established by the lack of EHP signal in the purified polymerizing THP. To determine the polymerization state of $\mathrm{THP}+\mathrm{EHP}$, we performed native immunoblots, and showed that $\mathrm{THP}+\mathrm{EHP}$ is present as a dimer in its native state (discrete, single band of MW around $242 \mathrm{kDa}$ marker), as compared to the multimeric native forms of urinary THP with characteristic ladder pattern (Figure 1B, right panel).

Detection of THP+ EHP in the kidney and its localization. We examined the presence of $\mathrm{THP}+\mathrm{EHP}$ in the human kidney using confocal immunofluorescence and found that $\mathrm{THP}+\mathrm{EHP}$ colocalizes with mature urinary THP in the thick ascending limbs, where it is maximally expressed at the apical domain (Figure 1C). This is not surprising and is consistent with release of $\mathrm{THP}+\mathrm{EHP}$ in the urine and its detection described above. However, a less intense but significant THP+EHP signal was also detected in other tubular segments such as proximal tubules (Figure 1C, right lower panel). 
medRxiv preprint doi: https://doi.org/10.1101/2021.02.26.21251982; this version posted March 2, 2021. The copyright holder for this preprint (which was not certified by peer review) is the author/funder, who has granted medRxiv a license to display the preprint in perpetuity. All rights reserved. No reuse allowed without permission.

Measuring THP+EHP in the urine and plasma of patients at risk for AKI. To facilitate the detection and quantitative measurements of THP+EHP in the plasma and urine, we designed a specific sandwich ELISA. Design and development details are provided in the methods and shown in Figure 2A. This effort required the generation of a synthetic hybrid THP+EHP calibrator peptide:

DRDNRDWVSVVTPARSVIDQSRVLNLGPITRKGVQAT (Figure 2A, right panel). THP+EHP and total THP (assayed using a commercially available ELISA) were then measured in the urine and plasma samples collected upon hospital admission from a cohort of 20 patients, half of whom subsequently developed hospital acquired AKI. These patients were part of a previously described study of hospitalized patients with liver cirrhosis (29), and they were included a priori, based on a case-control design, matching $\mathrm{AKI}$ cases with controls with similar age, gender, baseline kidney function, and severity of cirrhosis (Table 1). As expected, there were no significant differences between the two groups for demographics, co-morbid conditions, kidney function (baseline and admission), infections and severity of cirrhosis. Figures 2B and 2C show the measurements in the cohort (total and separated by AKI status), in urine and plasma, respectively.

THP+EHP is significantly decreased in patients who develop acute kidney injury. Urinary THP+EHP was markedly lower and constituted on average only $2.03 \pm 0.97 \%$ of total urinary THP. Interestingly, there was no significant correlation between THP+EHP and total urinary THP (Figure 2B, left panel), suggesting that their expression may be differentially regulated and arguing for an added value in their independent measurements. Specifically, only non-polymerizing THP+EHP (normalized to total urinary proteins) was significantly higher in patients who did not develop hospital 
medRxiv preprint doi: https://doi.org/10.1101/2021.02.26.21251982; this version posted March 2, 2021. The copyright holder for this preprint (which was not certified by peer review) is the author/funder, who has granted medRxiv a license to display the preprint in perpetuity. All rights reserved. No reuse allowed without permission.

acquired AKI (Figure 2B, middle and right panels), suggesting that this form of THP may be a sensitive indicator of kidney health and its susceptibility to acute injury.

$T H P+E H P$ is present in the circulation but at very low concentration. Plasma levels of THP+EHP were very low, constituting only $1.03 \pm 1.79 \%$ of total plasma THP. There was no difference in THP+EHP on admission in the plasma of patients with or without subsequent $\mathrm{AKI}$ (Figure $2 \mathrm{C}$ ), but there was a trend towards higher total plasma THP in those patients who did not develop AKI $(p=0.1)$, which is consistent with our previous findings (29). 
medRxiv preprint doi: https://doi.org/10.1101/2021.02.26.21251982; this version posted March 2, 2021. The copyright holder for this preprint (which was not certified by peer review) is the author/funder, who has granted medRxiv a license to display the preprint in perpetuity. All rights reserved. No reuse allowed without permission.

\section{Discussion}

In this work, we demonstrate that the kidney produces THP with retained EHP and releases it in the urine and serum. As expected, THP+EHP does not polymerize in its native state, which is consistent with the findings of Schaeffer et al in MDCK cells (42). The presence of THP+EHP at a molecular weight higher than mature urinary THP (slightly higher than $100 \mathrm{kDa}$ ) proves that we are not detecting a peptide fragment of THP, but a full-length protein. The release of THP+EHP in the urine could be explained by an alternative cleavage of GPI-linked THP distal to the 587-consensus cleavage site, thereby allowing the retention of the EHP domain. For example, GPI linked THP at S614 could be released from the membrane by the action of phospholipases and putative substrate-specific GPI-AP-releasing enzymes, such as NOTUM, glycerophosphodiesterase 2, and angiotensin-converting enzyme, which have been characterized in mammals (50). Another possible explanation could be the presence of an alternative minor pathway, whereby the carboxy-terminal is proteolyzed intracellularly without addition of the GPI anchor. Further studies are needed to elucidate the cellular mechanism underlying the release of THP+EHP, and the analytical tools generated by our work will be useful in performing these studies. However, the release of non-polymerizing THP+EHP in the urine remains a minor pathway, as most of the THP present is in the form of mature THP without EHP destined for polymerization.

In its native form, THP+EHP forms a dimer. This finding is consistent with our previous work where we isolated a truncated form of THP lacking part of the ZP domain (absent ZP-C domain and ending around amino acid 434) and showed that it could dimerize. It is possible that dimerization could be dependent on the ZP-N domain, independently 
medRxiv preprint doi: https://doi.org/10.1101/2021.02.26.21251982; this version posted March 2, 2021. The copyright holder for this preprint (which was not certified by peer review) is the author/funder, who has granted medRxiv a license to display the preprint in perpetuity. All rights reserved. No reuse allowed without permission.

from the ZP-C domain $(51,52)$. Dimerization could also be dependent on other factors, since it has been reported with other proteins harboring EGF-like domains (53). Further studies are needed to elucidate the mechanism of dimerization, and whether this is of biological relevance.

We demonstrated the colocalization of THP+EHP with mature THP in TAL cells within the human kidney using confocal microscopy. The predominant apical localization is consistent with its release and detection in the urine and suggests a cellular processing pathway similar to mature urinary THP, such as attachment to a GPI anchor at the apical membrane. The detection of lower levels of THP+EHP in other tubules suggest a possible basolateral release and uptake by other tubular segments within the kidney. It is possible that retaining the EHP could be an important mechanism by which THP is released into the kidney interstitium, parenchyma and circulation. If this proposition is true, we would then expect a significant detection of THP+EHP in the circulation. However, the low levels of THP+EHP in the circulation are intriguing and could be interpreted in various ways. We propose 2 non-exclusive explanations: 1) after its basolateral release, THP+EHP is significantly metabolized/processed within the kidney and scarcely released into the circulation and therefore, circulating THP may be independent of THP+EHP; 2) TAL cells use THP+EHP as an important process for basolateral release of THP, but it is further cleaved at the $\mathrm{C}$ terminus within the kidney or systemically, thereby preventing its detection by anti-EHP. The latter is supported by our previous findings that circulating THP is not aggregated (22) and by immunoblotting of immunoprecipitated serum vs. urinary THP, showing that the circulating form has a slightly higher molecular weight (Supplemental Figure 2) compared to mature urinary THP (close to $100 \mathrm{kDa}$, but still lower than THP+EHP which is > $100 \mathrm{kDa}$ ). We cannot 
medRxiv preprint doi: https://doi.org/10.1101/2021.02.26.21251982; this version posted March 2, 2021. The copyright holder for this preprint (which was not certified by peer review) is the author/funder, who has granted medRxiv a license to display the preprint in perpetuity. All rights reserved. No reuse allowed without permission.

rule out that differences in glycosylation may be also be an important factor in this shift in molecular weight. Future studies are required to elucidate the mechanisms of basolateral release and the role of THP+EHP.

Our findings may be relevant to future clinical applications by measuring nonpolymerizing THP as a biomarker for nephron function, reserve, and risk assessment. The data from the small clinical cohort suggest that THP+EHP may offer some advantages for risk assessment of kidney injury. Being non-polymerized, the levels of THP+EHP may be less susceptible to fluctuation that could be introduced by changes in the polymerization state. The ELISA developed in this study is less likely to detect proteolytic fragments, because of the requirement by this assay for an intact sequence between the epitopes used for capture and detection. Furthermore, the binding of antibodies may be more consistent in the setting of a non-aggregated protein, thereby causing less variability in the readout, and improving the accuracy and robustness of the measurements. Therefore, we propose that measurements of THP+EHP may offer improvements in representing functional nephron mass, reserve and the changes induced by disease, when added to total THP. Further studies are needed to test this hypothesis and establish the susceptibility of THP+EHP to degradation compared to mature urinary THP (54).

Our study is limited by the small sample size and requires independent validation in a larger study. The value of measuring THP+EHP as a sensitive and specific predictor for risk of $\mathrm{AKI}$ needs to be performed on a large scale, and it is premature to advocate its use outside of clinical research settings. 
medRxiv preprint doi: https://doi.org/10.1101/2021.02.26.21251982; this version posted March 2, 2021. The copyright holder for this preprint (which was not certified by peer review) is the author/funder, who has granted medRxiv a license to display the preprint in perpetuity. All rights reserved. No reuse allowed without permission.

In conclusion, we provide novel evidence that the kidney produces a non-polymerizing form of Uromodulin (THP) by retaining the EHP domain. Our findings suggest that this form of THP may be independently regulated and provide new insights into the biology of its synthesis and release, which will spur further research. We also provide proof-ofconcept data that measurements of this non-polymerizing form, using a de novo customized ELISA assay, could provide an independent value in assessing the risk of kidney injury, a finding that requires validation in larger studies. 
medRxiv preprint doi: https://doi.org/10.1101/2021.02.26.21251982; this version posted March 2, 2021. The copyright holder for this preprint

(which was not certified by peer review) is the author/funder, who has granted medRxiv a license to display the preprint in perpetuity.

All rights reserved. No reuse allowed without permission.

\section{AUTHOR CONTRIBUTIONS}

RM: designed reagents, performed experiments, analyzed data and drafted manuscript

KL: designed and performed experiments, analyzed data and drafted manuscript

KP: designed and performed clinical studies, collected specimens.

MSG: designed and performed clinical studies, collected specimens.

SK: performed experiments.

TME-A: oversaw and designed entire study, performed, and analyzed experiments, drafted manuscript.

All authors: edited and approved final draft.

\section{ACKNOWLEDGEMENTS}

This work was supported by funding from the Veteran Affairs (Merit Award to T.M.E.), the National Institute of Diabetes and Digestive and Kidney Diseases (1R01DK111651 to T.M.E), and P30DK079312- Indiana University O'Brien Center for Advanced Renal Microscopic Analysis. The authors would like to thank Drs. Katherine J. Kelly, and Daria Barwinska for assistance in experiments.

\section{DISCLOSURES}

The authors have applied for a patent to detect the non-polymerizing form of THP using the regents and ELISA tools that they developed.

\section{SUPPLEMENTAL MATERIAL TABLE OF CONTENTS}

Supplemental figures and figure legends
a.
Supplemental Figure 1
b. Supplemental Figure 2 
medRxiv preprint doi: https://doi.org/10.1101/2021.02.26.21251982; this version posted March 2, 2021. The copyright holder for this preprint (which was not certified by peer review) is the author/funder, who has granted medRxiv a license to display the preprint in perpetuity. All rights reserved. No reuse allowed without permission.

\section{REFERENCES}

1. Micanovic R, LaFavers K, Garimella PS, Wu XR, El-Achkar TM: Uromodulin (Tamm-Horsfall protein): guardian of urinary and systemic homeostasis. Nephrol Dial Transplant, 35: 3343, 2020 10.1093/ndt/gfy394

2. Rampoldi L, Scolari F, Amoroso A, Ghiggeri G, Devuyst O: The rediscovery of uromodulin (Tamm-Horsfall protein): from tubulointerstitial nephropathy to chronic kidney disease. Kidney Int, 80: 338-347, 2011 10.1038/ki.2011.134

3. Schaeffer C, Devuyst O, Rampoldi L: Uromodulin: Roles in Health and Disease. Annu Rev Physiol, 83: 477-501, 2021 10.1146/annurev-physiol-031620-092817

4. Bachmann S, Koeppen-Hagemann I, Kriz W: Ultrastructural localization of Tamm-Horsfall glycoprotein (THP) in rat kidney as revealed by protein A-gold immunocytochemistry. Histochemistry, 83: 531-538, 1985

5. Sikri KL, Foster CL, MacHugh N, Marshall RD: Localization of Tamm-Horsfall glycoprotein in the human kidney using immuno-fluorescence and immuno-electron microscopical techniques. J Anat, 132: 597-605, 1981

6. Dawnay $A B$, Cattell WR: Serum Tamm-Horsfall glycoprotein levels in health and in renal disease. Clin Nephrol, 15: 5-8, 1981

7. El-Achkar TM, McCracken R, Liu Y, Heitmeier MR, Bourgeois S, Ryerse J, et al.: TammHorsfall protein translocates to the basolateral domain of thick ascending limbs, interstitium, and circulation during recovery from acute kidney injury. Am J Physiol Renal Physiol, 304: F1066-1075, 2013 ajprenal.00543.2012 [pii] 10.1152/ajprenal.00543.2012

8. Steubl D, Block M, Herbst V, Nockher WA, Schlumberger W, Satanovskij R, et al.: Plasma Uromodulin Correlates With Kidney Function and Identifies Early Stages in Chronic Kidney Disease Patients. Medicine (Baltimore), 95: e3011, 2016 10.1097/MD.0000000000003011

9. Thornley C, Dawnay A, Cattell WR: Human Tamm-Horsfall glycoprotein: urinary and plasma levels in normal subjects and patients with renal disease determined by a fully validated radioimmunoassay. Clin Sci (Lond), 68: 529-535, 1985 10.1042/cs0680529

10. Kumar S, Muchmore A: Tamm-Horsfall protein--uromodulin (1950-1990). Kidney Int, 37: 1395-1401, 1990 10.1038/ki.1990.128

11. Pak J, Pu Y, Zhang ZT, Hasty DL, Wu XR: Tamm-Horsfall protein binds to type 1 fimbriated Escherichia coli and prevents $\mathrm{E}$. coli from binding to uroplakin la and $\mathrm{lb}$ receptors. J Biol Chem, 276: 9924-9930, 2001 10.1074/jbc.M008610200

12. Weiss GL, Stanisich JJ, Sauer MM, Lin CW, Eras J, Zyla DS, et al.: Architecture and function of human uromodulin filaments in urinary tract infections. Science, 369: 10051010, 2020 10.1126/science.aaz9866

13. Mutig K, Kahl T, Saritas T, Godes M, Persson P, Bates J, et al.: Activation of the bumetanide-sensitive $\mathrm{Na}+, \mathrm{K}+, 2 \mathrm{Cl}$ - cotransporter (NKCC2) is facilitated by TammHorsfall protein in a chloride-sensitive manner. J Biol Chem, 286: 30200-30210, 2011 10.1074/jbc.M111.222968

14. Renigunta A, Renigunta V, Saritas T, Decher N, Mutig K, Waldegger S: Tamm-Horsfall glycoprotein interacts with renal outer medullary potassium channel ROMK2 and regulates its function. J Biol Chem, 286: 2224-2235, 2011 10.1074/jbc.M110.149880

15. Tokonami N, Takata T, Beyeler J, Ehrbar I, Yoshifuji A, Christensen El, et al.: Uromodulin is expressed in the distal convoluted tubule, where it is critical for regulation of the sodium chloride cotransporter NCC. Kidney Int, 94: 701-715, 2018 10.1016/j.kint.2018.04.021

16. Trudu M, Janas S, Lanzani $C$, Debaix $H$, Schaeffer $C$, Ikehata $M$, et al.: Common noncoding UMOD gene variants induce salt-sensitive hypertension and kidney damage by increasing uromodulin expression. Nat Med, 19: 1655-1660, 2013 10.1038/nm.3384

17. Liu Y, Goldfarb DS, El-Achkar TM, Lieske JC, Wu XR: Tamm-Horsfall protein/uromodulin deficiency elicits tubular compensatory responses leading to hypertension and hyperuricemia. Am J Physiol Renal Physiol, 314: F1062-f1076, 2018 10.1152/ajprenal.00233.2017 
medRxiv preprint doi: https://doi.org/10.1101/2021.02.26.21251982; this version posted March 2, 2021. The copyright holder for this preprint

(which was not certified by peer review) is the author/funder, who has granted medRxiv a license to display the preprint in perpetuity. All rights reserved. No reuse allowed without permission.

18. Nie M, Bal MS, Liu J, Yang Z, Rivera C, Wu XR, et al.: Uromodulin regulates renal magnesium homeostasis through the ion channel transient receptor potential melastatin 6 (TRPM6). J Biol Chem, 2018 10.1074/jbc.RA118.003950

19. Wolf MT, Wu XR, Huang CL: Uromodulin upregulates TRPV5 by impairing caveolinmediated endocytosis. Kidney Int, 84: 130-137, 2013 10.1038/ki.2013.63

20. El-Achkar TM, McCracken R, Rauchman M, Heitmeier MR, Al-Aly Z, Dagher PC, et al.: Tamm-Horsfall protein-deficient thick ascending limbs promote injury to neighboring S3 segments in an MIP-2-dependent mechanism. Am J Physiol Renal Physiol, 300: F999F1007, 2011 ajprenal.00621.2010 [pii] 10.1152/ajprenal.00621.2010

21. El-Achkar TM, Wu XR, Rauchman M, McCracken R, Kiefer S, Dagher PC: Tamm-Horsfall protein protects the kidney from ischemic injury by decreasing inflammation and altering TLR4 expression. Am J Physiol Renal Physiol, 295: F534-544, 2008

22. Micanovic R, Khan S, Janosevic D, Lee ME, Hato T, Srour EF, et al.: Tamm-Horsfall Protein Regulates Mononuclear Phagocytes in the Kidney. J Am Soc Nephrol, 29: 841-856, 2018 10.1681/ASN.2017040409

23. Alesutan I, Luong TTD, Schelski N, Masyout J, Hille S, Schneider MP, et al.: Circulating uromodulin inhibits vascular calcification by interfering with pro-inflammatory cytokine signaling. Cardiovasc Res, 2020 10.1093/cvr/cvaa081

24. LaFavers KA, Macedo E, Garimella PS, Lima C, Khan S, Myslinski J, et al.: Circulating uromodulin inhibits systemic oxidative stress by inactivating the TRPM2 channel. Sci Transl Med, 11, 2019 10.1126/scitransImed.aaw3639

25. Micanovic R, Chitteti BR, Dagher PC, Srour EF, Khan S, Hato T, et al.: Tamm-Horsfall Protein Regulates Granulopoiesis and Systemic Neutrophil Homeostasis. J Am Soc Nephrol, 26: 2172-2182, 2015 ASN.2014070664 [pii] 10.1681/ASN.2014070664

26. Delgado GE, Kleber ME, Scharnagl H, Kramer BK, Marz W, Scherberich JE: Serum Uromodulin and Mortality Risk in Patients Undergoing Coronary Angiography. J Am Soc Nephrol, 2017 ASN.2016111162 [pii] 10.1681/ASN.2016111162

27. Leiherer A, Muendlein A, Saely $\mathrm{CH}$, Brandtner EM, Geiger K, Fraunberger $\mathrm{P}$, et al.: The value of uromodulin as a new serum marker to predict decline in renal function. $J$ Hypertens, 36: 110-118, 2018 10.1097/HJH.0000000000001527

28. Leiherer A, Muendlein A, Saely $\mathrm{CH}$, Ebner J, Brandtner EM, Fraunberger $P$, et al.: Serum uromodulin is a predictive biomarker for cardiovascular events and overall mortality in coronary patients. Int J Cardiol, 231: 6-12, 2017 10.1016/j.jicard.2016.12.183

29. Patidar KR, Garimella PS, Macedo E, Slaven JE, Ghabril MS, Weber RE, et al.: Admission plasma uromodulin and the risk of acute kidney injury in hospitalized patients with cirrhosis: a pilot study. Am J Physiol Gastrointest Liver Physiol, 317: G447-g452, 2019 10.1152/ajpgi.00158.2019

30. Scherberich JE, Gruber R, Nockher WA, Christensen EI, Schmitt H, Herbst V, et al.: Serum uromodulin-a marker of kidney function and renal parenchymal integrity. Nephrol Dial Transplant, 33: 284-295, 2018 10.1093/ndt/gfw422

31. Steubl D, Schneider MP, Meiselbach H, Nadal J, Schmid MC, Saritas T, et al.: Association of Serum Uromodulin with Death, Cardiovascular Events, and Kidney Failure in CKD. Clin J Am Soc Nephrol, 15: 616-624, 2020 10.2215/CJN.11780919

32. Bullen AL, Katz R, Lee AK, Anderson CAM, Cheung AK, Garimella PS, et al.: The SPRINT trial suggests that markers of tubule cell function in the urine associate with risk of subsequent acute kidney injury while injury markers elevate after the injury. Kidney Int, 96: 470-479, 2019 10.1016/j.kint.2019.03.024

33. Garimella PS, Biggs ML, Katz R, Ix JH, Bennett MR, Devarajan P, et al.: Urinary uromodulin, kidney function, and cardiovascular disease in elderly adults. Kidney Int, 88: 1126-1134, 2015 10.1038/ki.2015.192

34. Garimella PS, Jaber BL, Tighiouart $H$, Liangos $O$, Bennett MR, Devarajan $P$, et al.: Association of Preoperative Urinary Uromodulin with AKI after Cardiac Surgery. Clin $J$ Am Soc Nephrol, 12: 10-18, 2017 10.2215/CJN.02520316 
medRxiv preprint doi: https://doi.org/10.1101/2021.02.26.21251982; this version posted March 2, 2021. The copyright holder for this preprint

(which was not certified by peer review) is the author/funder, who has granted medRxiv a license to display the preprint in perpetuity.

All rights reserved. No reuse allowed without permission.

35. Jian L, Fa X, Zhou Z, Liu S: Functional analysis of UMOD gene and its effect on inflammatory cytokines in serum of essential hypertension patients. Int J Clin Exp Pathol, 8: 11356-11363, 2015

36. Radhakrishnan A, Price AM, Pickup LC, Law JP, McGee KC, Fabritz L, et al.: Coronary flow velocity reserve and inflammatory markers in living kidney donors. Int J Cardiol, 320: 141-147, 2020 10.1016/j.ijcard.2020.08.013

37. Bokhove M, Nishimura K, Brunati M, Han L, de Sanctis D, Rampoldi L, et al.: A structured interdomain linker directs self-polymerization of human uromodulin. Proc Natl Acad Sci U S A, 113: 1552-1557, 2016 10.1073/pnas.1519803113

38. Rindler MJ, Naik SS, Li N, Hoops TC, Peraldi MN: Uromodulin (Tamm-Horsfall glycoprotein/uromucoid) is a phosphatidylinositol-linked membrane protein. J Biol Chem, 265: 20784-20789, 1990

39. Serafini-Cessi F, Malagolini N, Hoops TC, Rindler MJ: Biosynthesis and oligosaccharide processing of human Tamm-Horsfall glycoprotein permanently expressed in HeLa cells. Biochem Biophys Res Commun, 194: 784-790, 1993 10.1006/bbrc.1993.1890

40. Stanisich JJ, Zyla DS, Afanasyev P, Xu J, Kipp A, Olinger E, et al.: The cryo-EM structure of the human uromodulin filament core reveals a unique assembly mechanism. Elife, 9, 2020 10.7554/eLife.60265

41. Stsiapanava A, Xu C, Brunati M, Zamora-Caballero S, Schaeffer C, Bokhove M, et al.: CryoEM structure of native human uromodulin, a zona pellucida module polymer. EMBO J: e106807, 2020 10.15252/embj.2020106807

42. Schaeffer C, Santambrogio S, Perucca S, Casari G, Rampoldi L: Analysis of uromodulin polymerization provides new insights into the mechanisms regulating ZP domainmediated protein assembly. Mol Biol Cell, 20: 589-599, 2009 10.1091/mbc.E08-08-0876

43. Brunati M, Perucca S, Han L, Cattaneo A, Consolato F, Andolfo A, et al.: The serine protease hepsin mediates urinary secretion and polymerisation of Zona Pellucida domain protein uromodulin. Elife, 4: e08887, 2015 10.7554/eLife.08887

44. Santambrogio S, Cattaneo A, Bernascone I, Schwend T, Jovine L, Bachi A, et al.: Urinary uromodulin carries an intact ZP domain generated by a conserved C-terminal proteolytic cleavage. Biochem Biophys Res Commun, 370: 410-413, 2008 10.1016/j.bbrc.2008.03.099

45. Cavallone D, Malagolini N, Monti A, Wu XR, Serafini-Cessi F: Variation of high mannose chains of Tamm-Horsfall glycoprotein confers differential binding to type 1-fimbriated Escherichia coli. J Biol Chem, 279: 216-222, 2004 10.1074/jbc.M308821200

46. Tamm I, Horsfall FL, Jr.: Characterization and separation of an inhibitor of viral hemagglutination present in urine. Proc Soc Exp Biol Med, 74: 106-108, 1950

47. Tamm I, Horsfall FL, Jr.: A mucoprotein derived from human urine which reacts with influenza, mumps, and Newcastle disease viruses. J Exp Med, 95: 71-97, 1952

48. El-Achkar TM, Plotkin Z, Marcic B, Dagher PC: Sepsis induces an increase in thick ascending limb Cox-2 that is TLR4 dependent. Am J Physiol Renal Physiol, 293: F11871196, 2007 10.1152/ajprenal.00217.2007

49. KDIGO Clinical Practice Guideline for Acute Kidney Injury. Kidney International Supplements, 2: 1-138, 2012

50. Fujihara Y, Ikawa M: GPI-AP release in cellular, developmental, and reproductive biology. $J$ Lipid Res, 57: 538-545, 2016 10.1194/jlr.R063032

51. Jovine L, Janssen WG, Litscher ES, Wassarman PM: The PLAC1-homology region of the ZP domain is sufficient for protein polymerisation. BMC Biochem, 7: 11, 2006 10.1186/1471-2091-7-11

52. Wilburn DB, Swanson WJ: The "ZP domain" is not one, but likely two independent domains. Mol Reprod Dev, 84: 284-285, 2017 10.1002/mrd.22781

53. Feinberg H, Uitdehaag JC, Davies JM, Wallis R, Drickamer K, Weis WI: Crystal structure of the CUB1-EGF-CUB2 region of mannose-binding protein associated serine protease-2. EMBO J, 22: 2348-2359, 2003 10.1093/emboj/cdg236

54. Youhanna S, Weber J, Beaujean V, Glaudemans B, Sobek J, Devuyst O: Determination of uromodulin in human urine: influence of storage and processing. Nephrol Dial Transplant, 29: 136-145, 2014 10.1093/ndt/gft345 
medRxiv preprint doi: https://doi.org/10.1101/2021.02.26.21251982; this version posted March 2, 2021. The copyright holder for this preprint (which was not certified by peer review) is the author/funder, who has granted medRxiv a license to display the preprint in perpetuity. All rights reserved. No reuse allowed without permission.

Table 1: Demographics and baseline characteristics of cohort of patients with cirrhosis

\begin{tabular}{|c|c|c|c|}
\hline & $\begin{array}{l}\text { No-AKI } \\
\mathrm{N}=10\end{array}$ & $\begin{array}{l}\text { Development of AKI } \\
\qquad N=10\end{array}$ & P-value \\
\hline Age (s.d) & $56.00(7.21)$ & $57.00(9.12)$ & 0.790 \\
\hline Gender, n (\%) male & $6(60)$ & $6(60)$ & 1.00 \\
\hline Race, n (\%) white & $8(80)$ & $10(100)$ & 0.474 \\
\hline \multicolumn{4}{|l|}{ Etiology of Cirrhosis, n (\%) } \\
\hline Hepatitis C & $2(20)$ & $2(20)$ & \\
\hline Hepatitis C and Alcohol & $2(20)$ & $0(0)$ & 0.539 \\
\hline Alcohol & $2(20)$ & $2(20)$ & \\
\hline Non-alcoholic Steatohepatitis & $4(40)$ & $5(50)$ & \\
\hline Other & $0(0)$ & $1(10)$ & \\
\hline History of Diabetes, n (\%) & $4(40)$ & $4(40)$ & 1.00 \\
\hline History of Hypertension, n (\%) & $5(50)$ & $4(40)$ & 0.470 \\
\hline History of Ascites, n (\%) & $6(60)$ & $9(90)$ & 0.303 \\
\hline Infection on Admission, n (\%) & $1(10)$ & $4(40)^{*}$ & 0.303 \\
\hline Baseline sCr, mg/dL (s.d) & $0.94(0.30)$ & $1.00(0.31)$ & 0.648 \\
\hline Baseline eGFR, $\mathrm{ml} / \mathrm{min} / 1.73 \mathrm{~m}^{2 *}(\mathrm{~s} . \mathrm{d})$ & $84.60(26.73)$ & $78.10(22.27)$ & 0.562 \\
\hline Admission Heart Rate (s.d) & $85.70(13.39)$ & $92.10(11.46)$ & 0.266 \\
\hline Admission MAP, mmHg (s.d) & $87.00(15.50)$ & $79.20(10.08)$ & 0.198 \\
\hline Admission WBC, $10^{9} / \mathrm{L}$ (s.d) & $8.10(4.90)$ & $8.27(3.88)$ & 0.932 \\
\hline Admission Hgb g/dL (s.d) & $10.85(2.28)$ & $9.90(1.47)$ & 0.284 \\
\hline Admission Platelet Count, k/cumm (s.d) & $106.79(67.06)$ & $98.20(32.46)$ & 0.363 \\
\hline Admission Serum Sodium, mmol/L (s.d) & $137.10(3.81)$ & $131.80(7.03)$ & 0.051 \\
\hline Admission sCr, mg/dL (s.d) & $0.98(0.30)$ & $1.14(0.43)$ & 0.364 \\
\hline Admission eGFR, $\mathrm{ml} / \mathrm{min} / 1.73 \mathrm{~m}^{2 *}(\mathrm{~s} . \mathrm{d})$ & $79.53(26.08)$ & $70.70(27.40)$ & 0.470 \\
\hline Admission Total Bilirubin, mg/dL (s.d) & $3.95(4.34)$ & $3.13(2.93)$ & 0.627 \\
\hline Admission Albumin, g/dL & $2.95(0.69)$ & $2.56(0.57)$ & 0.186 \\
\hline Admission INR (s.d) & $1.61(0.52)$ & $1.70(0.63)$ & 0.729 \\
\hline Admission MELD score (s.d.) & $15.50(6.13)$ & $17.20(5.71)$ & 0.506 \\
\hline
\end{tabular}

sCr: serum creatinine; eGFR: estimated glomerular filtration rate; MAP: mean arterial pressure; MELD: Model for Endstage Liver Disease

*Based on Chronic Kidney Disease Epidemiology Collaboration creatinine equation 

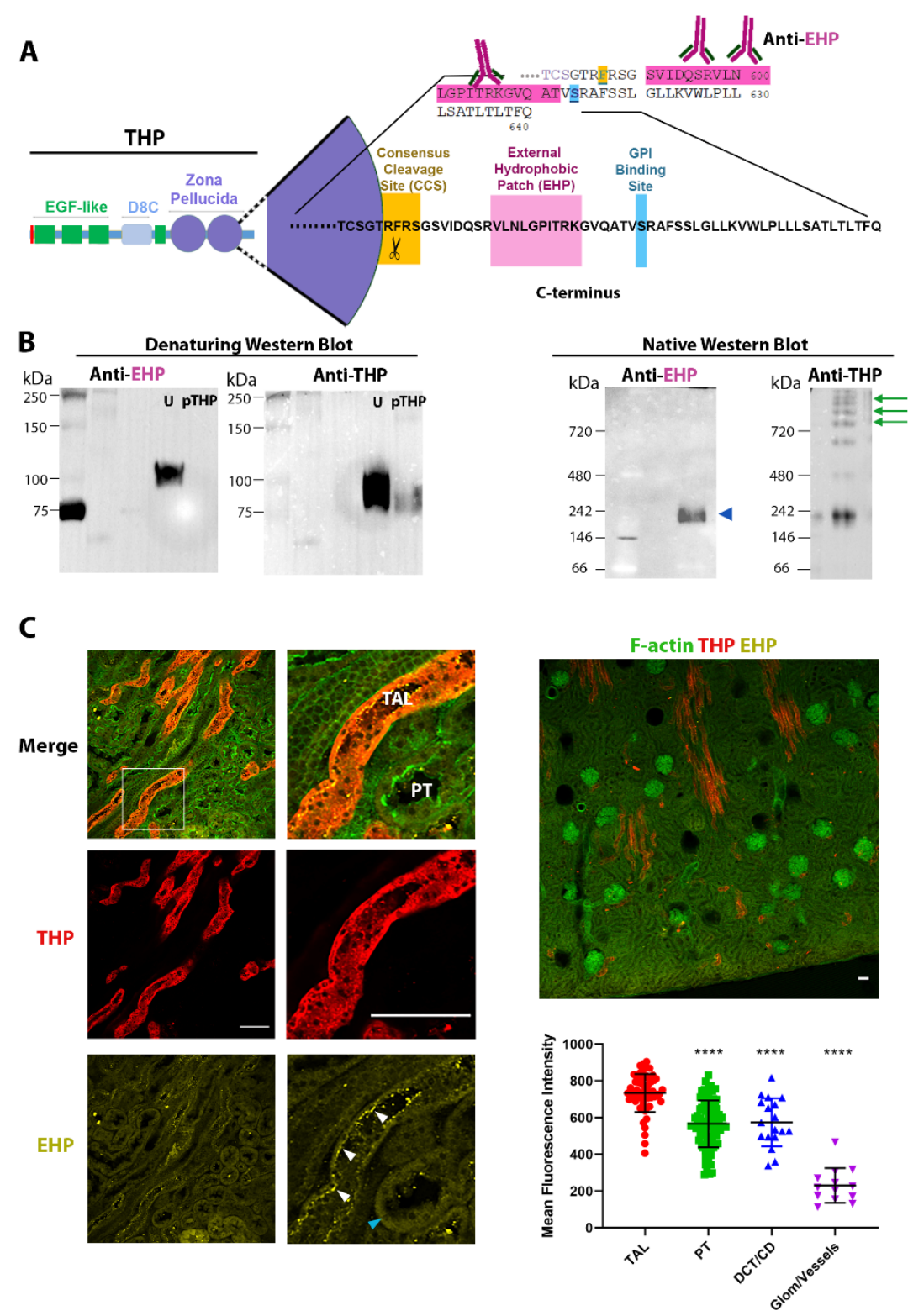

Figure 1: Non-polymerizing THP (Uromodulin) with retained external hydrophobic patch (EHP) is produced in the kidney

(A) Schematic representation of THP (Uromodulin) precursor with annotation of its functional domains, focusing on the $\mathrm{C}$ terminus (enlarged). An antibody against the indicated sequence encompassing the external hydrophobic patch (EHP) was developed.

(B) Left panel shows a denaturing immunoblot where THP with retained EHP (THP+EHP) is detected by anti-EHP in the urine (U). THP+EHP has higher MW than mature urinary THP, the latter detected by re-probing with an antibody (anti-THP) that was raised against mature urinary THP that lacks EHP. No EHP signal is detected in mature urinary polymerizing THP that was purified based on its aggregative properties (pTHP). Native separate immunoblots revealed that THP+EHP is a dimer in its native form (arrowhead, panel 2), whereas mature urinary THP without EHP polymerizes into high molecular weight multimers (arrows, panel 2).

(C) Immunofluorescence confocal microscopy of a human kidney section stained to detect THP and $\mathrm{THP}+\mathrm{EHP}$ (referred to as EHP in the figure). Representative images (high and low magnifications, left and right, respectively) are shown (scale bars $=100 \mu \mathrm{m})$. Non-polymerizing, THP+EHP colocalizes with mature THP in the thick ascending limbs (TAL) tubules, where it is maximally expressed at the apical domain (white arrows). However, a significant, albeit less intense THP+EHP signal, can also be detected in other segments such as proximal tubules (blue arrowhead). Quantitation of THP+ EHP signal per tubule type from 3 separate fields is shown in the graph. Asterisks denotes $\mathrm{P}<0.0001$. 
medRxiv preprint doi: https://doi.org/10.1101/2021.02.26.21251982; this version posted March 2, 2021. The copyright holder for this preprint (which was not certified by peer review) is the author/funder, who has granted medRxiv a license to display the preprint in perpetuity.

All rights reserved. No reuse allowed without permission.

A

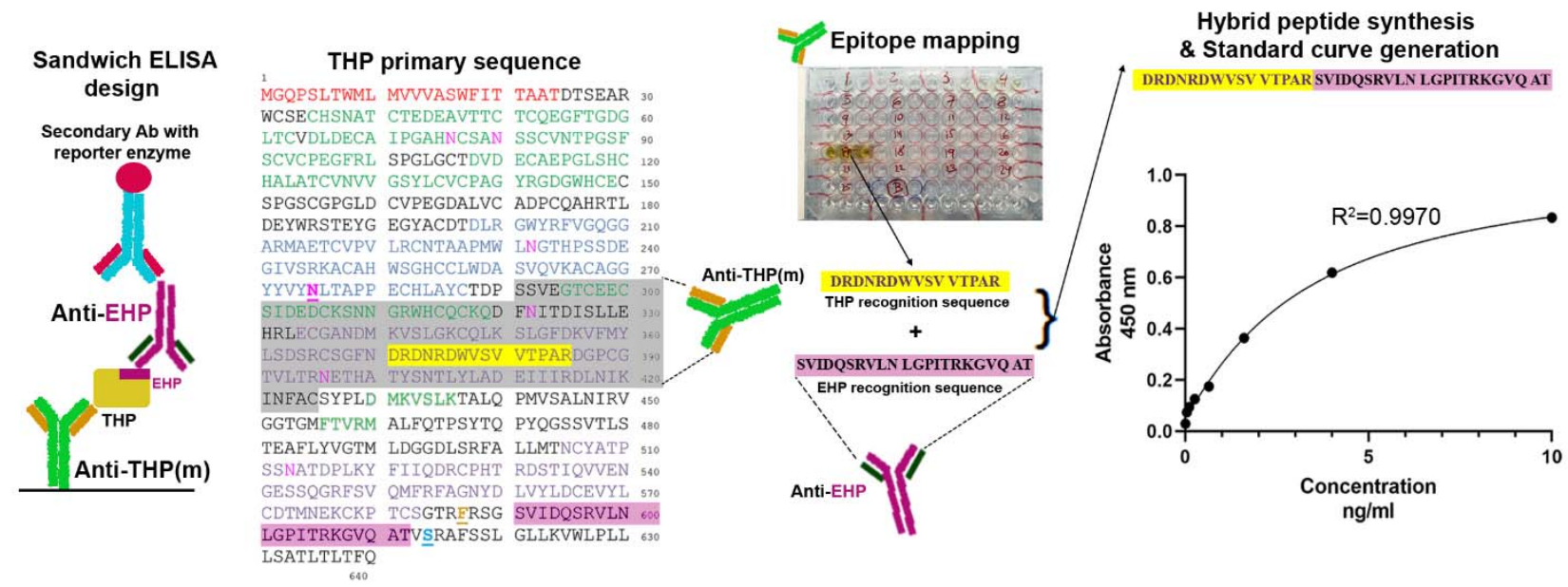

B
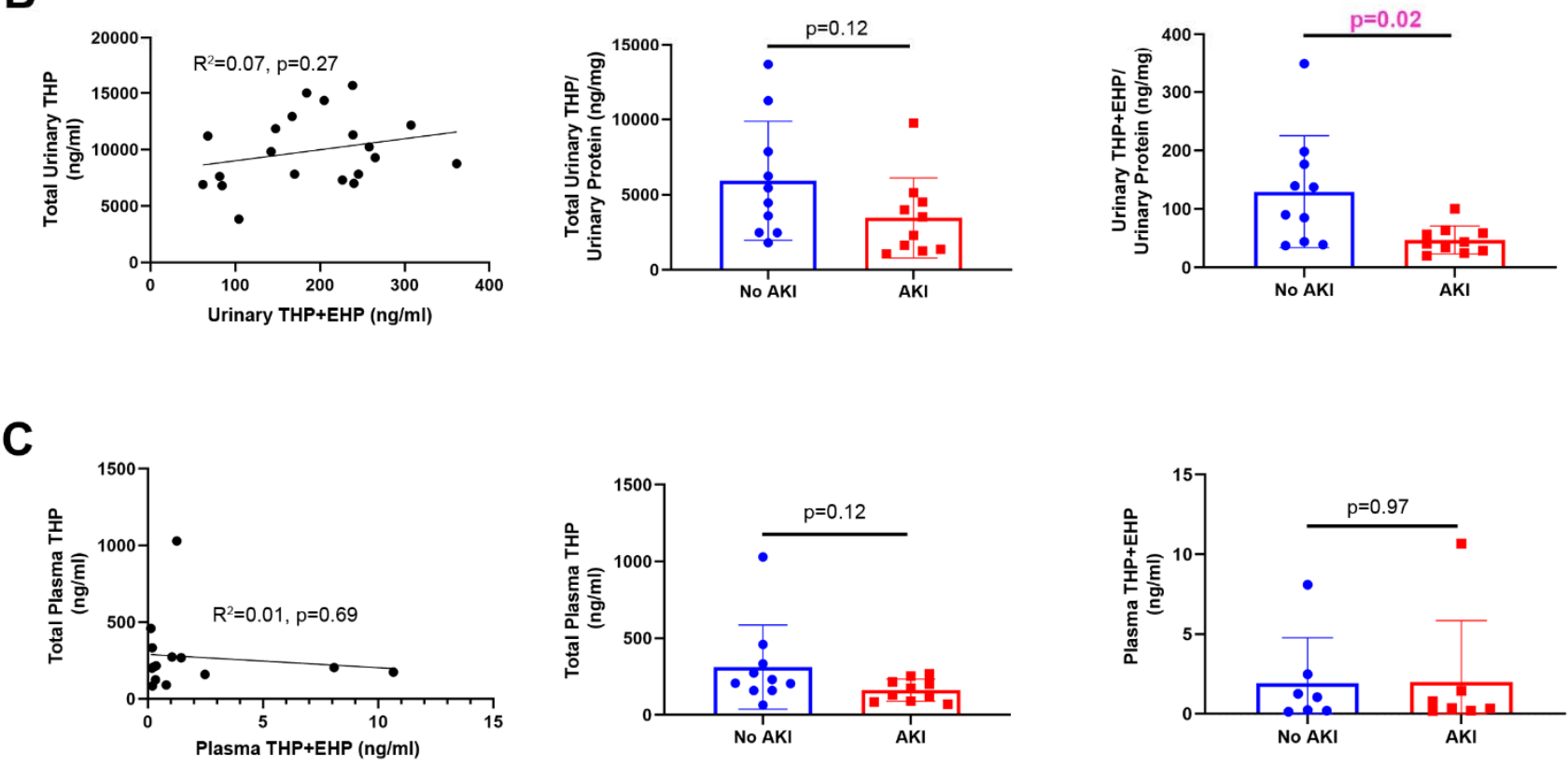

Figure 2: Design of a Sandwich ELISA using a hybrid synthetic peptide for calibration and detection of THP+EHP in the urine and serum of patients at risk for AKI.

(A) Design of sandwich ELISA for measurement of THP+EHP. Epitope mapping was performed for a commercially available monoclonal antibody (Anti-THP $(\mathrm{m})$ ) and a synthetic hybrid peptide combining the recognizable sequence in mature THP along with EHP sequence was generated for calibration. A representative standard curve using the hybrid peptide is shown in the panel on the right.

(B) Levels of non-polymerizing (THP+EHP) and total THP in the urine of a cohort of 20 patients with cirrhosis was measured on admission. Total and non-polymerizing THP did not have a direct significant correlation (left panel). After adjustment to total urinary proteins, only $\mathrm{THP}+\mathrm{EHP}$, but not total THP, was higher in patients who subsequently developed AKI (middle and right panels).

(C) THP+EHP was successfully measured in the serum, but the levels were very low, and did not associate with kidney injury. 